\begin{tabular}{|c|l|}
\hline Title & Monetary policy arithmetic for a deflationary economy \\
\hline Author(s) & Kudoh, Noritaka \\
\hline Citation & $\begin{array}{l}\text { Economics Letters, 87(2), 161-167 } \\
\text { https://loi.org/10.1016/.econlet.2004.10.011 }\end{array}$ \\
\hline Issue Date & 2005 -05 \\
\hline Doc URL & http://hdl.handle.net/2115/30147 \\
\hline Type & article(author version) \\
\hline File Information & EL87-2.pdf \\
\hline
\end{tabular}

Instructions for use 


\title{
Monetary Policy Arithmetic for a Deflationary Economy*
}

\author{
Noritaka Kudoh $^{\dagger}$ \\ Faculty of Economics, Kansai University
}

October 6, 2004

\begin{abstract}
This paper characterizes general properties of an economy that experiences deflation by investigating the long-run government budget constraint. A sufficient condition for deflation in an economy under a balanced budget is that the nominal interest rate is below the output growth rate. With a primary deficit, deflation occurs in a liquidity trap if the government is heavily in debt. Simple budget arithmetic reveals that it is never possible to finance a negative currency seigniorage by rolling over the public debt.
\end{abstract}

JEL classification: E42, E52, E58

Keywords: budget arithmetic, deflation

${ }^{*}$ I would like to thank an anonymous referee for helpful comments. I also would like to thank seminar participants at Kansai University, Osaka University, and the Mathematical Economics Conference in Kyoto for comments and discussions. Part of this research is financially supported by the Seimeikai foundation.

${ }^{\dagger}$ Noritaka Kudoh, Faculty of Economics, Kansai University, 3-3-35 Yamate, Suita, Osaka 564-8680 JAPAN; Tel: +81-6-6368-0631; fax: +81-6-6339-7704; E-mail: kudoh@ipcku.kansai-u.ac.jp 


\section{Introduction}

Recent years have witnessed the revival of theoretical studies into monetary policy and the surprising comeback of the liquidity trap and deflation in academia. Taylor (2001), for example, documents that the average inflation rate was $-0.5 \%$ in the $1995-2000$ period in Japan. The study of deflation is no longer a theoretical curiosum; deflation is a real economic issue.

There are several recent studies on deflation. In Benhabib et al. (2002) and Woodford (2001), for example, deflation occurs on the transition to a stationary state. However, in those frameworks, deflation will disappear when the economy reaches the stationary state. Can deflation be a longrun phenomenon? Under what circumstances is deflation likely to occur in the long run? The aim of this paper is to characterize some general properties of an economy with permanent deflation.

Sargent and Wallace (1981) were among the first to consider a consolidated government budget constraint, connecting monetary and fiscal policies. Their analysis revealed that the rate of inflation is strongly influenced by the needs of currency seigniorage. After Sargent and Wallace's (1981) contribution, many theoretical studies focused on the role of the government's budget constraint in determining the inflation rate and the price level. The literature typically focuses on fiscal aspects of inflation, and many implications are drawn from the public finance perspective. ${ }^{1}$ However, as compared to the literature on inflation, very little is known about a deflationary economy because until recently the world economy has been fighting inflation.

Instead of specifying a full general equilibrium model, this paper focuses on deriving implications of the consolidated government budget constraint for the long-run rate of inflation. In order to consider deflation in the long run, this paper primarily focuses on the steady-state budget constraint. The main findings from monetary policy arithmetic are: under a balanced budget, a sufficient condition for deflation is that the nominal interest rate is below the output growth rate; with a permanent deficit, deflation occurs when the government's total liabilities (money plus bonds) is large enough; it is never possible to finance a negative currency seigniorage by rolling over the public debt and therefore requires a sufficient budget surplus.

\footnotetext{
${ }^{1}$ For a brief review of the literature, see Bhattacharya and Haslag (1999). See also Miller (1983a, b)
} 


\section{The Government's Budget Constraint}

Let $t=1,2, \ldots$ index time. Consider a growing economy and let $Y_{t}$ and $p_{t}$ denote the real output and the price level at date $t$. Suppose that the economy grows at the gross rate $n$. How the price level, output, and demands for assets are determined is not specified. Instead, this paper focuses on the relations between key variables under deflation. The flow government budget constraint is given as

$$
G_{t}=T_{t}+B_{t}-I_{t} B_{t-1}+M_{t}-M_{t-1}
$$

where $G_{t}$ is the nominal government spending, $T_{t}$ is the nominal tax receipt, $B_{t}$ is the stock of one-period nominal bonds, $M_{t}$ is the nominal money balance, and $I_{t}$ is the gross nominal interest rate. (1) states that government expenditures are financed by taxes, bonds, and money. Since the economy starts from date $1, B_{0}=M_{0}=0$ must hold. It follows that at date 1 the government budget is $G_{1}=T_{1}+B_{1}+M_{1}$. In this economy money is supplied via open market purchases.

Divide (1) by $Y_{t} p_{t}$ to obtain

$$
g_{t}=\tau_{t}+b_{t}-\frac{I_{t}}{\pi_{t} n} b_{t-1}+m_{t}-\frac{1}{\pi_{t} n} m_{t-1},
$$

where $g_{t} \equiv G_{t} / Y_{t} p_{t}$ measures the real government spending per output, $\tau_{t} \equiv T_{t} / Y_{t} p_{t}$ measures the real tax per output, $b_{t} \equiv B_{t} / Y_{t} p_{t}$ measures the real debt outstanding per output, and $m_{t} \equiv M_{t} / Y_{t} p_{t}$ measures the real money balance per output.

Suppose that there is a stationary state in which all per output real variables are constant over time. Then the stationary government budget constraint satisfies

$$
g=\tau+\left(1-\frac{I}{\pi n}\right) b+\left(1-\frac{1}{\pi n}\right) m
$$

where the second term of the right-hand-side is the bond seigniorage and the final term is the currency seigniorage. For (3) to hold, it is necessary that $g<\tau+b+m$.

Notice that the stationary government budget constraint implies that there are two possible definitions of deflation. One is the conventional definition, where the rate of inflation is negative, which simply requires $\pi<1$. The other possible definition is $\pi n<1$, under which the currency seigniorage is negative. 
Definition 1 (a) An economy with $\pi<1$ is said to experience a weak deflation. (b) An economy with $\pi n<1$ is said to experience a strong deflation.

Of course, the two deflations coincide when the output growth rate is zero, or $n=1$. If the output growth rate is positive $(n>1)$, then the government's revenue from printing money is positive as long as $\pi>1 / n$ is satisfied. The condition does not require a positive inflation rate. Thus, from the public finance perspective there is no distinction between a deflationary economy and an inflationary economy unless $\pi>1 / n$ is violated. If the condition is violated, then deflation is strong enough to make the currency seigniorage negative. Since, under $n>1$ the condition $\pi<1$ is weaker than $\pi n<1$, the former is referred to as 'weak' definition while the latter is 'strong.' Since the two definitions are the same under $n=1$, this paper considers the general case in which $n \geq 1$.

Since $m_{t}=m_{t-1}$ must hold in the steady state, $M_{t}=\pi n M_{t-1}$ must hold as well, which states that the gross money growth rate is $\pi n$ in the steady state. This implies that the nominal money stock shrinks over time under strong deflation. On the other hand, the stock of money can be growing under weak deflation. It is now evident that strong deflation is a situation where the rate of money growth is negative while weak deflation is defined as the rate of inflation being negative.

Before proceeding, it is important to clearify how the analysis in this paper differs from the fiscal theory of the price level, which is popularized by, for example, Woodford (2001). The heart of the theory is to assume the so called non-Ricardian policy regime, under which the government commits to paths of the primary deficit and the revenue from printing money. In such an economy the government's budget constraint is satisfied only at the equilibrium price level. ${ }^{2}$ The analysis in this paper assumes a Ricardian regime: it views the government budget constraint as an identity rather than an equation. Thus, the results in this paper are derived by analyzing how the variables must be related under deflation, given that the identity holds.

\footnotetext{
${ }^{2}$ See Christiano and Fitzgerald (2000) for a survey.
} 


\section{Deflation in the Weak Sense}

This section considers an economy with weak deflation, under which the rate of inflation is negative while the currency seigniorage is positive. Rewrite the government budget constraint (3) as

$$
\pi=\frac{1}{n} \frac{I b+m}{b+m+\tau-g} .
$$

From (4), it is easy to check that $\pi<1$ holds if and only if $n>[I b+m][b+m-d]^{-1} \equiv \phi$, where $d \equiv g-\tau$ is the primary deficit. That is, for a weak deflation, the output growth rate should not be too small. It is also easy to show that $\partial \phi / \partial d>0$, which implies that an increase in the primary deficit will make it difficult for deflation to occur. Thus, from the public finance perspective, stagnated economies with large deficits are more likely to be inflationary rather than deflationary.

Consider once again (4), from which $\pi<1$ holds if and only if

$$
n \frac{d}{b}<(n-I)+(n-1) \frac{m}{b}
$$

It states that for a weak deflation, the deficit-to-debt ratio must be small, the output growth rate must be greater than the nominal interest rate, and the money-to-bonds ratio must be sufficiently large. The same condition can be expressed differently as

$$
\frac{i}{n} b+d<\frac{n-1}{n}(b+m)
$$

where $i \equiv I-1$ is the net nominal interest rate. According to this expression, $\pi<1$ is obtained if $d$ is small and $i$ is small.

In order to obtain a sharp result, assume for now that $g=\tau$. Then, it follows that in the steady state, setting the nominal interest rate at $I<n$ is sufficient for $\pi<1$. Loosely speaking, $I$ measures the growth rate of the government-issued nominal assets. Thus, $I<n$ implies that goods expand more rapidly than nominal assets, raising the relative price of money: the economy is deflationary. The result is consistent to some extent with the historical observation that deflation occurs in an economy that is considered to be trapped in a liquidity trap, a situation in which the economy hits the lower bound of the nominal interest rate, such as the US economy in the 
1930's and the Japanese economy in recent years. The recent literature, such as Benhabib et al. (2002), stresses the importance of the zero lower bound of the nominal interest rate for deflation. By contrast, the result above implies that what matters is the level of the nominal interest rate relative to the output growth rate.

Another interesting special case, of course, is when $i=0$, under which the economy is in a liquidity trap. In that case, by (6), $\pi<1$ and

$$
\frac{d}{b+m}<\frac{n-1}{n}
$$

imply each other. This condition states that the deficit as a fraction of the total government liabilities must be small enough. It simply requires fiscal surplus for an economy with $n=1$. For a growing economy with deficit, the condition requires that the government is heavily in debt. The Japanese economy in recent years seems to be in a situation similar to this: the government is heavily in debt and follows a loose monetary policy; the nominal interest rate is near zero; the money growth rate is positive (i.e., it cannot be a strong deflation). ${ }^{3}$

To summarize,

Proposition 2 (a) In a stationary state under a balanced budget, a sufficient condition for a weak deflation is that the nominal interest rate is below the output growth rate. (b) In a liquidity trap with a primary deficit, a weak deflation occurs if and only if the deficit-to-liability ratio is sufficiently small.

The present analysis attempts to derive implications from the government budget constraint without introducing rational individuals and therefore without any welfare criterion. For that reason one cannot make a presumption as to whether deflation should be avoided. However, it is worth studying how deflation can be avoided, without making any normative statement. (6) implies that, to avoid deflation, the government can simply run a large permanent deficit. Raising the nominal interest rate would also work because an increase in the interest rate raises the interest obligation on the debt outstanding, which raises the need for currency seigniorage.

\footnotetext{
${ }^{3}$ According to the latest report by Nippon Keidanren (Japan Business Federation), the debt-GDP ratio is projected to reach 5 in 2025 .
} 
The analysis so far might give the impression that a budget surplus causes deflation. However, the analysis in this paper is incapable of expounding causalities because there is no clear distinction between endogenous and exogenous variables: all variables are treated equally. It is certainly odd to state that the central bank is forced to reduce currency seigniorage because the fiscal authority is running a surplus. It seems more appealing to state instead that deflation must be financed by a budget surplus.

A related question here is whether inflation is possible under a permanent budget surplus. The answer is yes. Consider (6). If the budget surplus $(-d)$ is sufficiently large, then it looks like inflation is impossible. It is, however, legitimate to ask if the government might still want to borrow under a large fiscal surplus. Under a permanent surplus, the government is lending, and money is supplied via open market purchases of private assets, such as stocks and gold. It is helpful to rewrite (6) and show that $\pi>1$ holds if and only if

$$
\frac{n-1}{n}(l-m)<\frac{i}{n} l+(\tau-g)
$$

where $l \equiv-b$. It is then easy to see that inflation is perfectly possible under a budget surplus.

\section{Deflation in the Strong Sense}

For a strong deflation, what matters is whether the currency seigniorage is negative or not. Let $R_{t}$ denote the gross real interest rate on bonds. Use the Fisher equation, $I_{t}=R_{t} \pi_{t}$, to rewrite (3) to obtain

$$
g=\tau+\left(1-\frac{R}{n}\right) b+\left(1-\frac{1}{\pi n}\right) m
$$

As is well-known, the government's revenue from issuing bonds (the second term of (8)) is positive if and only if the economy is dynamically inefficient. An economy with $R<n$ is said to be dynamically inefficient, and in such an economy the government can roll over the debt forever. ${ }^{4}$ Let

\footnotetext{
${ }^{4}$ Of course, it does not mean that the government can finance all the revenue needs by issuing bonds. Chalk (2000) shows that the government cannot borrow too much although it can roll over the debt forever. See Bhattacharya and Kudoh (2002) for a monetary counterpart of Chalk (2000).
} 
$s^{b} \equiv(1-R / n) b$ and $s^{m} \equiv(1-1 / \pi n) m$ denote the bond seigniorage and the currency seigniorage. Then, (8) becomes $g=\tau+s^{b}+s^{m}$. Since strong deflation is defined by $s^{m}<0$, it is easy to verify that a strong deflation occurs if $g<\tau+s^{b}$ : the government's revenue from tax and bonds exceeds its spending. One might argue that a strong deflation may occur if the bond seigniorage is sufficiently large. The guess turns out be wrong.

Proposition 3 It is never possible to finance a strong deflation by rolling over the public debt.

Proof. Since the nominal interest rate is bounded at zero, $I>1$ must hold. From the Fisher equation it is easy to show that $I=R \pi>1$, implying $R / n>1 / n \pi$. Thus, when a strong deflation occurs $(1 / n \pi>1)$, the economy is necessarily characterized as being dynamically efficient $(R / n>1)$.

Since the currency seigniorage and the bond seigniorage are both negative under strong deflation, in a stationary state a strong deflation occurs only if the government runs a permanent budget surplus. In other words, if somehow the economy experiences a strong deflation, then the government will be forced to run a primary surplus.

Consider once again (4). Then, it is easy to show the following.

Proposition 4 A stationary state is strongly deflationary if and only if

$$
i<\frac{\tau-g}{b} \text {. }
$$

That is, a strong deflation occurs if and only if the net nominal interest rate is less than the surplus-to-debt ratio. If there is a permanent budget deficit, then (9) implies that the economy is likely to be inflationary even when the economy is in a liquidity trap (i.e., $i=0$ ).

It is now clear that a strong deflation is a situation in which (i) the money growth rate is negative; (ii) the government runs a primary surplus; (iii) the government is in debt; and (iv) the nominal interest rate is low. Conditions (iii) and (iv) are easily met in the real world. However, condition (ii) is not. One possible interpretation is that strong deflation is simply unlikely because after all the governments around the globe run primary deficits rather than surpluses. According to this interpretation, strong deflation has no practical importance at least in the long run. 
Another possible interpretation is that if somehow the economy experiences a strong deflation, then the government will be forced to run a primary surplus. In the literature it is often documented that the central bank should follow the Friedman rule, under which the nominal interest rate is zero and money shrinks over time. Proposition 4 implies that the government must run a primary surplus in order to implement the Friedman rule.

\section{Conclusion}

This paper explored implications of the steady-state government budget constraint to characterize some general properties of an economy under deflation. Many results are derived without any reference to how rational individuals might behave. Introducing such agents and specifying a full general equilibrium model will certainly rule out some of the cases explored here. The advantage of the present analysis, however, is precisely that it allows one to study a broader set of cases.

An important limitation of the analysis is that it focuses on the steady state. If the steady state under consideration is unstable, for example, then it is possible that the debt will grow without bounds. In such a case, the government will not be able to commit to its original policy regime forever, which raises the possibility of a regime shift. It is therefore worth exploring the model in a non-stationary environment. 


\section{References}

[1] Benhabib, J., Schmitt-Grohe, S., Uribe, M., 2002. Avoiding liquidity traps. Journal of Political Economy 110, 535-563.

[2] Bhattacharya, J., Haslag, J.H., 1999. Monetary policy arithmetic: some recent contributions. Federal Reserve Bank of Dallas Economic Review, 26-36.

[3] Bhattacharya, J., Kudoh, N., 2002. Tight money policies and inflation revisited. Canadian Journal of Economics 35, 185-217.

[4] Chalk, N.A., 2000. The sustainability of bond-financed deficits: an overlapping generations approach. Journal of Monetary Economics 45, 293-328.

[5] Christiano, L., Fitzgerald, T., 2000. Understanding the fiscal theory of the price level. Federal Reserve Bank of Cleveland Economic Review 36, 2-37.

[6] Miller, P.J., 1983a. Higher deficit policies lead to higher inflation. Federal Reserve Bank of Minneapolis Quarterly Review 7.

[7] Miller, P.J., 1983b. Budget deficit mythology. Federal Reserve Bank of Minneapolis Quarterly Review 7.

[8] Sargent, T.J., Wallace, N., 1981. Some unpleasant monetarist arithmetic. Federal Reserve Bank of Minneapolis Quarterly Review 5.

[9] Taylor, J., 2001. Low inflation, deflation, and policies for future price stability. Monetary and Economic Studies 19, 35-51.

[10] Woodford, M., 2001. Fiscal requirements for price stability. Journal of Money, Credit, and Banking 33, 669-728. 